\title{
Restless legs syndrome in Parkinson's disease
}

\section{Clinical characteristics and biochemical correlations}

\author{
Tiago Machado Guerreiro', Danilo Ryuko Cândido Nishikawa', \\ Lis Campos Ferreira², Hyder Aragão de Melo³, \\ Roberto César Pereira do Prado ${ }^{4}$
}

\begin{abstract}
Restless legs syndrome (RLS) is a neurological disorder that responds to dopaminergic drugs, indicating a common pathophysiology with Parkinson's disease (PD). The prevalence of RLS was estimated in a group of PD patients and its clinical and biochemical characteristics were analysed. Forty-eight patients with PD were evaluated into two groups, with and without RLS. Clinical characteristics assessed in both groups were age, gender, duration of PD, Hoehn and Yahr, and Schwab and England scales. Laboratory variables such as hemoglobin, s-iron, s-ferritin and creatinine were obtained. The prevalence of RLS was $18.75 \%$. No significant differences regarding clinical variables and biochemical parameters were observed. The high prevalence of RLS found in PD patients suggests the concept of a common etiological link and it seems that secondary causes did not play a central role in the pathophysiology of RLS in this group of parkinsonian patients.
\end{abstract}

Key words: restless legs syndrome, Parkinson's disease, prevalence, ferritin.

\section{Síndrome das pernas inquietas na doença de Parkinson: características clínicas e correlações bioquímicas}

\section{RESUMO}

A síndrome das pernas inquietas (SPI) é um distúrbio sensitivo-motor que responde aos agentes dopaminérgicos, demonstrando uma possível semelhança fisiopatológica com a doença de Parkinson (DP). Foi avaliada a prevalência da SPI em um grupo de pacientes com DP e suas características clínicas e laboratoriais. Quarenta e oito pacientes diagnosticados com DP foram divididos em dois grupos: com e sem SPI. Características clínicas como idade, sexo, duração da DP, escalas de Hoehn e Yahr, e Schwab e England e achados bioquímicos como hemoglobina, ferro sérico, ferritina sérica e creatinina foram obtidos. A freqüência da SPI foi de 18,75\%. Não se observaram diferenças estatisticamente significativas quanto às características clínicas e aos achados bioquímicos. A alta prevalência de SPI encontrada em pacientes com DP sugere associação entre essas duas doenças. É provável que causas secundárias não exerçam papel central na fisiopatologia da SPI nesse grupo de pacientes parkinsonianos.

Palavras-chave: síndrome das pernas inquietas, doença de Parkinson, prevalência, ferritina.

\section{Correspondence}

Roberto César Pereira do Prado Av. Coronel Stanley Silveira 73 - 319/321 49015-400 Aracaju SE - Brasil

E-mail: rcprado@infonet.com.br

Received 27 January 2010

Received in final form 3 May 2010

Accepted 12 May 2010
Restless legs syndrome (RLS) is a movement disorder characterized by an imperative urge to move the legs associated with uncomfortable sensations, paraesthesias and motor restlessness. These symptoms worsen during rest, mainly at night, with at least temporary relief brought on by activity ${ }^{1}$. It has a circadian pattern and af- 
fects onset and continuity of sleep due to the unpleasant sensations at bedtime ${ }^{2}$. The prevalence rates of RLS vary with age, gender, causes (primary or secondary) and in different ethnic populations. In general population its prevalence range between $0.8 \%$ and $15 \%^{2,3}$. Most people who are affected are middle-aged or older women.

The pathophysiology of RLS remains unclear and it is either genetic or secondary to other medical conditions, such as neuropathy, iron deficiency, renal failure, pregnancy and, possibly, rheumatoid arthritis ${ }^{4}$. In most cases, serum ferritin and iron-binding saturation should be obtained for serum iron deficiency, and electrolytes should be obtained for renal failure ${ }^{5}$. Familial cases of RLS demonstrating autosomal dominant pattern of inheritance are well-know described. Recent clinical and functional imaging data suggest impaired central dopaminergic transmis$\operatorname{sion}^{6}$. Thus, dopaminergic drugs have been widely accepted as an efficacy therapy for RLS, and dopamine medications currently represents the first-line treatment for this disorder ${ }^{3,7}$.

RLS was first described by Ekbom in 1945 and it has remained as a defined clinical diagnosis since then. Diagnostic criteria was established by the International Restless Legs Study Group (IRLSSG) ${ }^{8,9}$.

The aim of the present study was to investigate the prevalence, clinical characteristics and biochemical correlations of restless legs syndrome amongst Parkinson's disease (PD) patients.

\section{METHOD}

This study was carried out in a Movement Disorder Outpatient Clinic in the Federal University of Sergipe from January 2007 to December 2007. Forty-eight $(\mathrm{N}=48)$ patients with PD were recruited. The ethic committee of the Federal University of Sergipe has approved this study, and all subjects gave their informed consent to take part in the investigation.

The diagnosis of PD was made previously by a specialist in movement disorders using the UKPD Society Brain Bank criteria ${ }^{10}$. PD patients with diabetes mellitus, renal failure, anemia and rheumatoid arthritis were excluded from the study. The diagnosis of RLS was established by face-to-face interviews based upon the criteria of the International Restless Legs Syndrome Study Group. ${ }^{8}$ The criteria comprises a set of four questions: [1] desire to move the limbs usually associated with paresthesias/dysesthesias; [2] motor restlessness; [3] symptoms which are worse or exclusively present at rest (i.e., lying and sitting) with at least partial and temporary relief by activity; and [4] symptoms are worse in the evening or night. The diagnosis is made when all the above four criteria were met ${ }^{9}$.

After making the diagnosis of RLS, PD patients were divided into two groups: those with RLS and those without RLS. Clinical characteristics assessed in both groups were age, gender, duration of PD, severity (Hoehn and Yahr scale) ${ }^{11}$ and activities of daily living scale (Schwab and England scale $)^{12}$ of PD. Biochemical parameters such as such as hemoglobin, s-iron, s-ferritin and creatinine were obtained.

Following, comparisons of clinical and biochemical variables between each group were made. SPSS (v. 15.0) statistical software was used and statistical analyses by Mann-Whitney test, Chi-square, Fisher exact test and Student $t$ test.

\section{RESULTS}

A total of 48 patients were recruited. The estimated prevalence of RLS found among PD patients in our Movement Disorder Clinic was 18.75\% (9 patients).

Table 1. Comparison of clinical and biochemical findings between Parkinsonian patients with and without restless legs syndrome (Outpatient in University Hospital/ Federal University of Sergipe - January 2007 to December 2007).

\begin{tabular}{lccc}
\hline & Positive RLS group $(\mathrm{n}=9)$ & Negative RLS group $(\mathrm{n}=39)$ & $\mathrm{P}$ \\
\hline Age (years) & $67.11 \pm 9.47$ & $63.92 \pm 11.46$ & 0.443 \\
Masculine gender (\%) & 77.80 & 87.20 & 0.471 \\
PD duration (years) & $9.55 \pm 5.45$ & $7.35 \pm 3.59$ & 0.277 \\
Hoehn and Yahr & $2.83 \pm 0.93$ & $2.51 \pm 1.19$ & 0.309 \\
Schwab and England (\%) & $65.55 \pm 27.43$ & $71.02 \pm 26.33$ & 0.640 \\
Hemoglobin (g/dl) & $13.41 \pm 1.71$ & $13.55 \pm 1.28$ & 0.829 \\
Serum iron (mcg/dl) & $78.50 \pm 35.05$ & $90.64 \pm 33.88$ & 0.306 \\
Serum ferritin (ng/ml) & $145.87 \pm 72.09$ & $157.70 \pm 138.53$ & 0.530 \\
Urea (mg/dl) & $37.50 \pm 9.29$ & $34.84 \pm 14.88$ & 0.083 \\
Creatinine (mg/dl) & $1.04 \pm 0.26$ & $1.04 \pm 0.27$ & 0.971 \\
\hline
\end{tabular}

Positive RLS group: group of parkinsonian patients with restless legs syndrome; Negative RLS group: group of parkinsonian patients without restless legs syndrome; PD: Parkinson's disease; Normal range of hemoglobin: 13-17 g/dl; Normal range of serum iron: 35-150 mcg/dl; Normal range of serum ferritin: 16.4$253 \mathrm{ng} / \mathrm{ml}$; Normal range of urea: $15-39 \mathrm{mg} / \mathrm{dl}$; Normal range of creatinine: $0.6-1.3 \mathrm{mg} / \mathrm{dl}$. 
Table 2. Comparison of Hoehn and Yahr grades between Parkinsonian patients with and without restless legs syndrome (Outpatient in University Hospital/ Federal University of Sergipe - January 2007 to December 2007).

\begin{tabular}{lcc}
\hline & \multicolumn{2}{c}{ Hoehn e Yahr scale } \\
\cline { 2 - 3 } & $\leq 2.5$ & $>2.5$ \\
\hline Positive RLS group (\%) & $3(33 \%)$ & $6(67 \%)$ \\
Negative RLS group (\%) & $25(64 \%)$ & $14(36 \%)$ \\
\hline
\end{tabular}

Positive RLS group: group of parkinsonian patients with restless legs syndrome; Negative RLS group: group of parkinsonian patients without restless legs syndrome.

On those diagnosed with RLS (positive RLS group), the mean age was $67.11 \pm 9.47$ years and the mean duration of PD was $9.55 \pm 5.45$ years. $77.80 \%$ were men and $22.20 \%$ were women (Table 1 ).

The mean Hoehn and Yahr (UPDRS part V) score found was $2.83 \pm 0.93$ and in the Schwab and England scale (UPDRS part VI) was $65.55 \pm 27.43 \%$ (Table 1). Only three $(\mathrm{N}=3)$ patients $(33 \%)$ showed Hoehn and Yahr (UPDRS part V) grades lower than 2.5 (Table 2).

Data obtained by biochemical variables, such as hemoglobin, s-ferritin, s-iron and creatinine are registered on Table 1. Only one $(\mathrm{N}=1)$ patient showed s-ferritin value lower than $45 \mathrm{ng} / \mathrm{ml}$ on positive RLS group.

On the other group of PD patients, those without RLS (negative RLS group), the mean age found was $63.92 \pm 11.46$ years and the mean duration of PD was $7.35 \pm 3.59$ years. $87.20 \%$ were men and $12.80 \%$, women (Table 1 ).

In the negative RLS group, the mean Hoehn and Yahr score found was $2.51 \pm 1.19$ and in the Schwab and England scale was $71.02 \pm 26.33 \%$ (Table 1). Up to $64 \%$ patients showed Hoehn and Yahr scores lower than 2.5 (Table 2).

Biochemical parameters assessed on negative RLS group are reported in Table 1.

No significant differences between the two groups regarding age, gender, duration of $\mathrm{PD}$ and severity of $\mathrm{PD}$ (Hoehn and Yahr scale), activities of daily living scale (Schwab and England scale) were observed. Biochemical parameters did not differ between on those PD patients with RLS and on those without RLS (Table 1).

\section{DISCUSSION}

The prevalence rate of RLS in PD patients appears to be higher than in general population. It may vary from one survey to another since earlier studies have not used the full set of four diagnostic criteria of the IRLSSG ${ }^{8}$. Any series not using the full criteria simply were not considered valid. This study was performed following that questionnaire during all face-to-face interviews.

A RLS prevalence of $18.75 \%$ was estimated among this series of PD patients. Of 48 PD patients, 9 fulfilled the diagnosis criteria. Ondo et al. ${ }^{13}$ and Gomez et al. ${ }^{14}$ had found prevalence rates of $20.8 \%$ and $21.9 \%$, respectively. Although, Nomura et al. ${ }^{15}$ and Krishnan et al. ${ }^{16}$ were not able to replicate these findings in their series of PD patients estimating prevalence rates of $12 \%$ and $7.9 \%$, respectively. The higher prevalence noted among our group of PD patients may corroborate for the hypotheses of similar pathology between RLS and PD.

PD patients with RLS were older than those without RLS but there was no statistical difference between RLS and non-RLS groups (positive RLS: 67.11 \pm 9.47 years; negative RLS: $63.92 \pm 11.46$ years; $\mathrm{p}=0.443$ ). This finding is consisted with that reported by Gómez et al. ${ }^{14}$, who found no statistical difference (positive RLS: $69.8 \pm 8.8$ years; negative RLS: $68.4 \pm 9.7$ years) among their series of 114 patients with PD, and also with Calzetti et al. ${ }^{17}$ (positive RLS: $71.0 \pm 4.5$ years; negative RLS: $68.0 \pm 8.0$ ). In an Indian survey ${ }^{16}$, they reported a significant difference of mean age between PD patients with and without RLS (positive RLS: $63.70 \pm 7.8$ years; negative RLS: $57.37 \pm 10.04$ years; $\mathrm{p}=0.05$ ). Nomura and associates ${ }^{15}$, however, concluded that PD patients without RLS seemed to be younger that those with RLS (positive RLS: $59.7 \pm 2.7$ years; negative RLS: $70.1 \pm 0.8$ years; $\mathrm{p}=0.0001$ ).

The subjects included in the positive RLS group were mostly men (seven of nine patients). Krishnan et al. ${ }^{16} \mathrm{e}$ Tan et al. ${ }^{7}$ have found similar gender distribution. This result is not noted by others and RLS has been found to be more prevalent in female. Studies have reported prevalence two or three times higher among female subjects with RLS. Gómez et al. ${ }^{14}$ found 25 (21.9\%) patients with RLS among their PD patients and on this group, 17 (68\%) were female and 8 (32\%) male.

In the present study, most of the RLS patients (67\%) were in an advanced stage of PD (Hoehn and Yahr scale score $>2.5$ ). The mean score in the positive RLS group was $2.83 \pm 0.93$ and the mean score in the negative RLS was $2.51 \pm 1.19$. Although, there was no significant difference between those two groups. Similar findings have been reported by others as Krishnan et al. ${ }^{16}$ and Ondo et al. ${ }^{13}$.

Previous studies raised the possibility that low level of serum ferritin may be related with the occurrence of RLS in PD patients since iron has a role in both biosynthesis and transmission of monoamines. It is known that low iron level leads to dopaminergic dysfunction. Its deficiency decreases density of dopamine D2 and D1 receptors in the caudate-putamen. In the series of 18 patients with RLS and 18 controls, O'Keeffe et al. ${ }^{18}$ found serum ferritin levels significantly lower in the patients with RLS (positive RLS: $33 \mathrm{ng} / \mathrm{ml}$; negative RLS: $59 \mathrm{ng} / \mathrm{ml}$; $\mathrm{p}<0.01$ ). Although, in this study no statistical difference of serum ferritin level was found between positive RLS group and negative RLS group. Ondo et al. ${ }^{13}$ and Nomura et al. ${ }^{17}$ have reported similar findings. 
Only one patient with RLS had serum ferritin levels $<45 \mathrm{ng} / \mathrm{ml}$. Winkelmann et al. ${ }^{19}$ recommend iron replacement if ferritin levels are $<50 \mathrm{ng} / \mathrm{ml}$, even though this level is considered to be in normal range. The same authors have reported that lower ferritin levels are also associated with greater RLS severity and decreased sleep efficiency, with increasing waking time after sleep onset. O'Keeffe et al. ${ }^{18}$ treated patients who had serum ferritin levels $<45$ $\mathrm{ng} / \mathrm{ml}$ with iron replacement obtaining partial relief of RLS symptoms.

This study suffers from certain limitations collecting biochemical data since most of the sample of PD patients comprises subjects mostly from the suburbs of Aracaju, the countryside as well as nearby states, Alagoas and Bahia. This fact is responsible for the reduced number of patients.

All patients were interviewed and examined personally by the author in order to avoid bias during the development of our study with false-positive or false-negative findings.

In conclusion, the present study suggests that RLS occurs more frequently in patients with PD. Moreover, there was no statistical difference comparing clinical and biochemical characteristics between subjects with RLS and without RLS. It seems that secondary causes of RLS did not play a central role in the pathophysiology of RLS in this group of parkinsonian patients.

We reiterate the importance of diagnosis of RLS in patients with PD, since disturbances in sleep is significantly more frequent in parkinsonian patients than in healthy population and it may worsen their quality of life. Studies with larger sample are necessary to explore the relationship of RLS in brazilian patients with PD.
ACKNOWLEGMENT - The authors thank all patients for participating in the study.

\section{REFERENCES}

1. Miranda M, Araya F, Castillo JL, et al. Restless legs syndrome: a clinical study in adult general population and in uremic patients. Rev Méd Chile 2001;129: 179-186.

2. Allen RP, Montplaisir J, Walters AS. Restless legs syndrome prevalence and impact: REST general population study. Arch Intern Med 2005;165: 1286-1292.

3. Alóe F, Tavares SMA. Síndrome das pernas inquietas: artigo de revisão. Rev Neurociências 2006;14: 204-213.

4. Montplaisir J, Allen RP, Walters AS, et al. Restless legs syndrome and Periodic limb movement disorders. In: Kryger MH, Roth T, Dement WC (Eds). Principes and practice of sleep medicine. Philadelphia, Saunders 2005:830-852.

5. Ondo WG. Restless legs syndrome. Neurol Clin 2009;27:779-799.

6. Borrreguero DG, Odin P, Serrano C. Restless legs syndrome and PD: a review of the evidence for a possible association. Neurology 2003;65 (Suppl): S49-S55.

7. Tan EK, Lum SY, Wong, MC. Restless legs syndrome in Parkinson's disease. $J$ Neurol Sci 2002;102:33-36.

8. Walters AS. Toward a better definition of the restless legs syndrome: the International Restless Legs Syndrome Study Group. Mov Disord 1995;10:634-642.

9. American Academy of Sleep Medicine. Restless legs syndrome. International Classification of Sleep Disorders. Diagnostic and Coding Manual. Westchester, IL: American Academy of Sleep Medicine 2005;2:178-181.

10. Hughes AJ, Daniel SE, Blankson S, Lees AJ. A clinicopathologic study of 100 cases of Parkinson disease. Arch Neurol 1993;50:140-148.

11. Hoehn MM, Yahr MD. Parkinsonism: onset, progression and mortality. Neurology 1967;17: 427-442.

12. Schwab RS, England AC Jr. Parkinson's disease: rehabilitation aspects. Rehab Literature 1961;22:326-336.

13. Ondo WG, Vuong KD, Jankovic J. Exploring the relationship between Parkinson disease and restless legs syndrome. ArchNeurol 2002;59:421-424.

14. Gómez JC, Zarranz JJ, Tijero B, et al. Restless legs syndrome in Parkinson's disease. Mov Disord 2007;22:1912-1916.

15. Nomura T, Inoue Y, Miyake M. et al. Prevalence and clinical characteristics of restless legs syndrome in japanese patients with Parkinson's disease. Mov Disord 2006;21:380-384.

16. Krishnan PR, Bathia M, Behari M. Restless legs syndrome in Parkinson's disease: a case-controlled study. Mov Disord 2002;18:181-185.

17. Calzetti S, Negrotti A, Bonavina G, et al. Absence of co-morbidity of Parkinson disease and restless legs syndrome: a case-control study in patients attending a movement disorders clinic. Neurol Sci 2009;30:119-122.

18. O'Keeffe ST, Gavin K, Lavan JN. Iron status and restless legs syndrome in the elderly. Age Ageing 1994;23:200-203.

19. Winkelmann J, Allen R, Tenzer P, et al. Restless legs syndrome: nonpharmacologic and pharmacologic treatments. Geriatrics 2007;62:13-16. 